\title{
Population structures of three Calliptamus spp. (Orthoptera: Acrididae) across the Western Mediterranean Basin
}

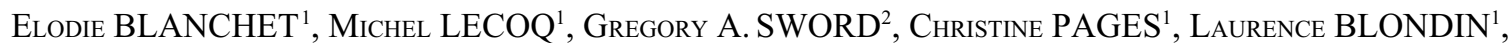 \\ Claire BILlOT ${ }^{3}$, Ronan RIVALLAN ${ }^{3}$, Antoine FOUCART ${ }^{1}$, JeAn-Michel VASSAL $^{1}$, Ange-Marie RISTERUCCI $^{3}$ \\ and MARIE-PIERRE CHAPUIS

\begin{abstract}
${ }^{1}$ CIRAD UPR Bioagresseurs: Analyse et maîtrise du risque, F-34398 Montpellier, France; e-mails: blanchet.elodie@gmail.com; lecoq@cirad.fr; christine.pages@cirad.fr; laurence.blondin@cirad.fr; antoine.foucart@cirad.fr; jean-michel.vassal@cirad.fr; marie-pierre.chapuis@cirad.fr

${ }^{2}$ Department of Entomology, Texas A\&M University, College Station, TX 77842-2475, USA; e-mail: gasword@tamu.edu
\end{abstract} \\ ${ }^{3}$ CIRAD, UMR AGAP, F-34398 Montpellier, France; e-mails: claire.billot@cirad.fr; ronan.rivallan@cirad.fr; risterucci@cirad.fr
}

Key words. Orthoptera, Acrididae, Calliptamus, population genetic, microsatellite, closely related species, potential pests

\begin{abstract}
We conducted a comparative population genetic analysis of levels of genetic variation and its geographical structuring in three closely related species of grasshopper that co-occur in the Mediterranean Basin: Calliptamus italicus, C. barbarus and C. wattenwylianus. In the western part of their distributions 5 populations of $C$. italicus, 13 of $C$. barbarus and 10 of $C$. wattenwylianus were sampled. Bootstrap re-sampling of populations and microsatellite loci within each species indicated a lower level of genetic diversity and higher level of genetic differentiation in C. barbarus, which is less of an outbreak pest species than either of the other Calliptamus species studied. This may be due to lower effective sizes of non-outbreak populations and/or lower gene flow among them.
\end{abstract}

\section{INTRODUCTION}

Locusts and grasshoppers of the family Acrididae (Orthoptera) are among the most devastating pests of pastures and crops in many parts of the World (Steedman, 1988; Latchininsky et al., 2011). Periodically there are huge increases in the local abundance of locusts, with individuals actively aggregating and forming migratory bands and swarms that are highly destructive (Uvarov, 1966, 1977; Belayneh, 2005; Magor et al., 2008; Sword et al., 2010). The most notorious locust species is the Desert locust, Schistocerca gregaria gregaria (Forskål, 1775), with a huge distribution spanning Africa and the Middle East. This species in Africa damages crops over an area of 14 million ha (Lecoq, 2003). The high propensity for migration and capacity for long distance dispersal of gregarious Desert locusts are illustrated by recurrent reports of swarms observed flying $100 \mathrm{~km}$ or more downwind in 9 or $10 \mathrm{~h}$ (FAO, 1994).

In contrast to swarming locusts, other grasshopper pests can cause more chronic and local yield losses. Grasshopper pests of major importance occur world-wide, for example, the Senegalese Grasshopper Oedaleus senegalensis (Krauss, 1877) in the entire Indo-Saharan zone, the Rice Grasshopper Oxya hyla (Serville, 1831) in the tropical areas of the Old world, Dichroplus maculipennis (Blanchard, 1851) in South America (COPR, 1982) and Calliptamus italicus (Linné, 1758) from the Mediterranean Basin to central Asia (COPR, 1982). As an illustration, areas invaded by the latter species during outbreaks are 80,000 ha in South Western France and over 420,000 ha in the area of the Aral sea (Latchininsky \& Gapparov, 1996).

Assessing how the ecological features (intrinsic to population) can structure intraspecific genetic variation has been attempted in some locust species (Zheng et al., 2006; Chapuis et al., 2008; Zhang et al., 2009). Life histories of locusts are characterized by high fecundity and mobility, which are both likely to result in a low population genetic structure. The propensity to outbreak itself may play a major role in homogenizing genetic variation, even at a continental scale (Chapuis et al., 2009). Such a high level of gene flow may result from changes in migratory behaviour shown by locusts in the gregarious phase, which is induced by crowding (Pener \& Simpson, 2009; Simpson \& Sword, 2009; Simpson et al., 2011). Alternatively, but non-exclusively, outbreak locust populations may have extremely large effective population sizes, thereby strongly reducing the rate of genetic drift and differentiation (Chapuis et al., 2011). Despite the possible implications for management, the patterns of genetic variation in natural populations and how they relate to intrinsic factors are rarely investigated in nonlocust grasshopper pests. However, the population dynamics and structure of non mass-migrating grasshoppers are likely to differ from that of locusts.

Species belonging to the genus Calliptamus spp. (Orthoptera: Acrididae) provide a good biological model for studying levels and geographical structuring in the genetic variation in grasshopper pests. The genus includes fifteen species world-wide (COPR, 1982). Amongst them, C. italicus (Linné, 1758), C. barbarus (Costa, 1836) and 


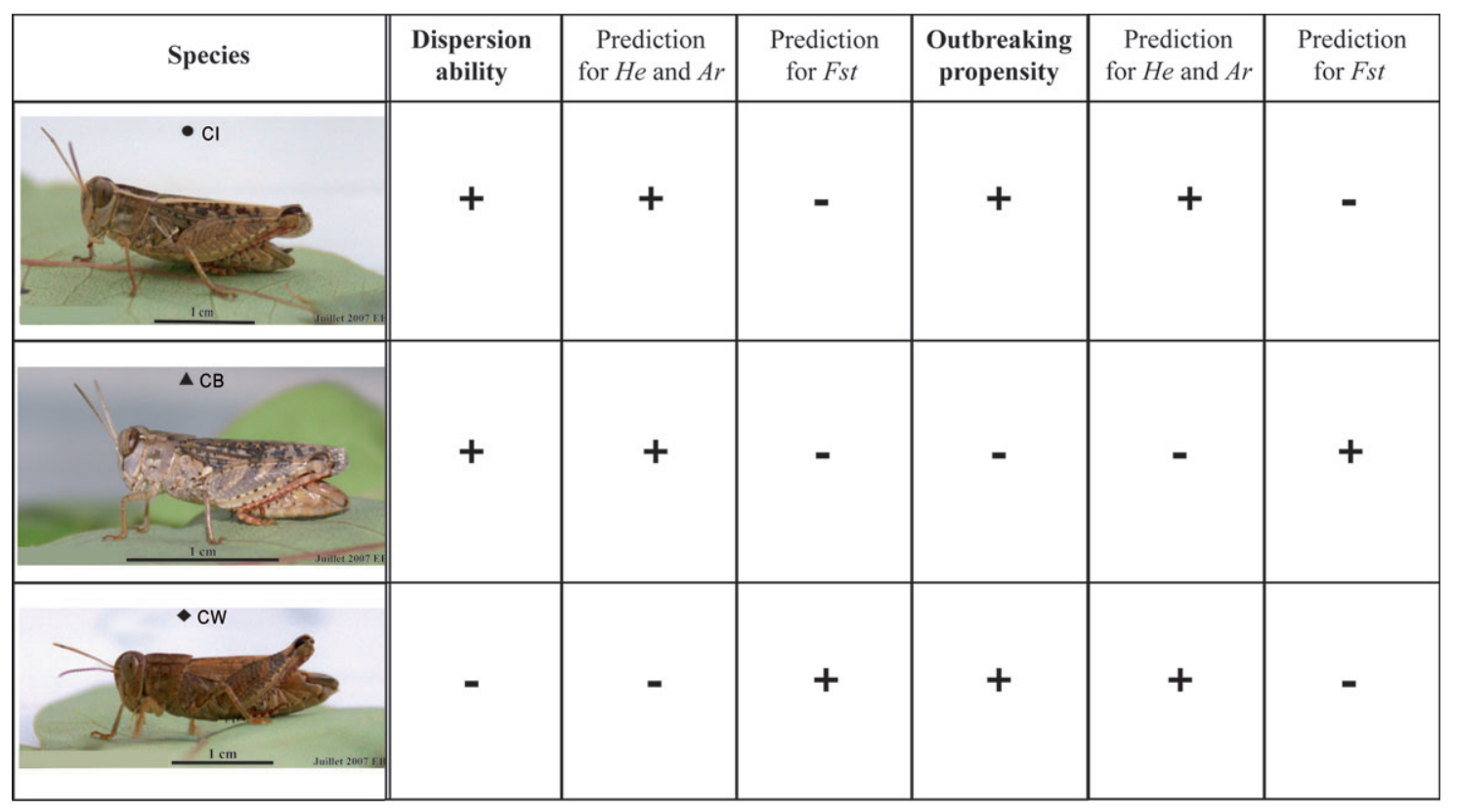

Fig. 1. Comparison of the predicted levels of genetic diversity and differentiation in the three species of Calliptamus studied. Calliptamus italicus (CI; circle); C. barbarus (CB; triangle) and C. wattenwylianus (CW; diamond).

C. wattenwylianus (Pantel, 1896) are syntopic across the western part of Mediterranean Basin. C. italicus and $C$. barbarus have the widest distributions, from the Mediterranean Basin to southern Siberia, whereas C. wattenwylianus is recorded only along the Mediterranean coasts of France, Spain, Morocco and Algeria. Morphological discrimination between the juvenile stages and adult females of these three closely related species is ambiguous, whereas adult males can be identified based on the shape of their wings and pallium (Jago, 1963; Harz, 1975). However, the three species can be easily differentiated genetically, with sequence divergences in Cytochrome Oxidase I mtDNA estimated to be over 3\% (Blanchet et al., 2010b). These three species of grasshopper damage crops (COPR, 1982) and share some general ecological features, such as, a one-year generation time, a seasonal diapause, feed on grass (Poacea) (Chopard, 1951) and a moderate dispersal ability (Reinhardt et al., 2005). Given that these three species co-occur and are closely related, ecological and evolutionary factors that affect one species are likely to affect the others, therefore a comparison of these species might provide insights into the relative importance of the factors that shape genetic structuring (McCoy et al., 2005; Brouat et al., 2007).

Although the three species of Calliptamus studied are closely related, ecologically similar, and syntopic, previous studies report fine-scale differences between them in terms of ecological features and neutral genetic variation (see Fig. 1). Firstly, Blanchet et al. (2012) showed that at a scale of $70 \mathrm{~km}^{2}$ between sites in Southern France, gene flow was restricted only in C. wattenwylianus, a species thought to be relatively sedentary compared to other congeneric species (Chara, 1987). Indeed, Jago (1963) showed that $C$. italicus and $C$. barbarus have a higher wing/body length ratio, which is a reliable proxy of dis- persal ability, than $C$. wattenwylianus. Secondly, the same fine-scale microsatellite study highlighted lower levels of genetic diversity in $C$. barbarus than in $C$. italicus and $C$. wattenwylianus. This result suggests that long-term effective sizes of populations of $C$. barbarus might be lower than those of the other species in the two locations studied. Interestingly, all three species are agricultural pests, but $C$. barbarus only causes slight damage to crops relatively rarely, whereas $C$. wattenwylianus and $C$. italicus are well known for the damage they do to crops in many countries (COPR, 1982). In order to determine and generalize the local patterns across the species' respective ranges, more extensive population samples are required.

In this study, we sampled populations throughout the ranges in the distributions common to all three species. We then used microsatellite markers to assess whether the levels of intra-specific genetic variation and its geographical structuring differed in the three species of $\mathrm{Cal}$ liptamus at this wide range scale.

\section{MATERIAL AND METHODS}

\section{Population sampling and genotyping}

Because it is not possible to unambiguously identify juveniles and adult females of the three species (C. italicus, C. barbarus, C. wattenwylianus) based on their morphology (Jago, 1963; Harz, 1975), we sampled only adult males. Although males disperse more than females in most Orthopteran species (e.g. Bailey et al., 2007; Ortego et al., 2011) male-based sampling is not likely to have biased the inferred patterns in genetic structure because the maximum distances dispersed by the species studied are likely to be much shorter than the distances between the populations studied.

During spring and summer 2008, we collected samples from populations in France, Spain, Italy, Morocco, Algeria and Uzbekistan (see Fig. 2). This sampling regime covers most of the distribution of $C$. wattenwylianus and the south-western parts of the distribution ranges of C. italicus and C. barbarus. 


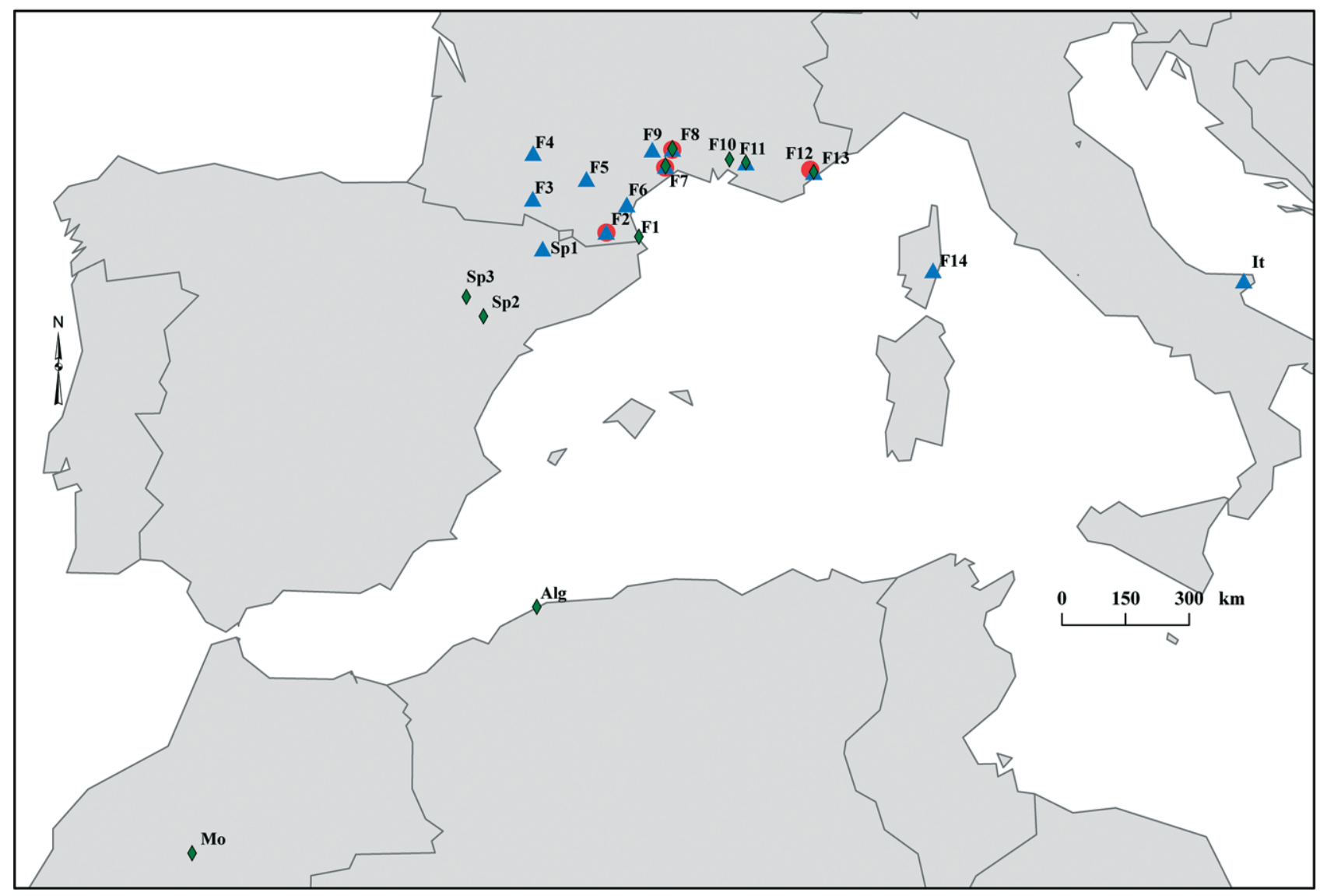

Fig. 2. Geographical distributions in the Western Mediterranean Basin of the 28 populations of the three species of Calliptamus sampled. Circle - C. italicus, triangle - C. barbarus, diamond - C. wattenwylianus. F1-F2: localities 1 and 2 in the region Pyrénées Orientales; F3: Ariège, F4: Gers, F5: Tarn, F6: Aude, F7-9: Hérault, F10-11: Bouches-du-Rhône, F12-13: Var, F14: Corsica, Mo: Morocco, Alg: Algeria (Chlef), Sp: Spain: Sp1: Cataluña, Sp2-3: Aragón, It: Italy (Puglia). For good graphical resolution the location of the sample of the Uzbekistan population of $C$. italicus is not included in this map. This sample is termed "Uz" in the main text, tables and figures.

We collected samples from a total of 13,10 and 5 populations of C. barbarus, C. wattenwylianus and C. italicus, respectively (with 10 to 68 individuals per sample). Henceforth in the text, these species will be referred to as $C B, C W$ and $C I$, respectively. Areas sampled for the three species were relatively similar in size. Distances between the populations of C. barbarus and $C$. wattenwylianus sampled were similar, ranging from $30 \mathrm{~km}$ to $1300 \mathrm{~km}$ and from $30 \mathrm{~km}$ to $1700 \mathrm{~km}$, respectively. For C. italicus the geographical distances between populations ranged from $30 \mathrm{~km}$ to $410 \mathrm{~km}$ except for pairs that included the Uzbekistan population, which is a very long way from where most of the populations were sampled in the western part of their ranges (about $4500 \mathrm{~km}$ ).

In terms of outbreak history, most $C$. barbarus outbreaks are reported in the eastern part of its distribution (COPR, 1982) and more recently slight damage has been recorded by this species in North Africa (Doumandji et al., 1993), two regions not included in the area sampled for this species. In contrast, outbreaks of $C$. italicus are recorded across most of its wide range, in particular in the western Mediterranean region, including Spain, Italy and France (del Cañizo, 1940; Alléguède, 1946; Louveaux et al., 1988; Buzzetti et al., 2005). C. wattenwylianus is a very important crop pest, but because of its more restricted geographical distribution, its damage is limited to the southern part of the area we sampled, which includes Spain (E. Muniez, pers. comm.) and North Africa (Doumandji et al., 1993) (e.g. localities Sp2, Sp3 and Alg; Fig. 1).

Samples were genotyped using seven microsatellite loci for C. barbarus (CB18, CB8, CB14, CB1, CB2, CB9, CB17), six for C. italicus (CB18, CB8, CB14, CI9, CI2 CI11) and three for C. wattenwylianus (CB18, CB14, CI9) (Blanchet et al., 2010a). Note that microsatellite primer pairs used for $C W$ were all designed from the closely-related species ( $C B$ and $C I)$; similarly, half of the microsatellite primer pairs used for $C I$ were designed from $C B$. Two microsatellite loci were amplified across all three species (CB18 and CB14). For detailed information about microsatellite markers and PCR conditions, see Blanchet et al. (2010a). When samples failed to amplify at some loci, replicate PCRs were conducted for these loci. Note that loci were not the same for all species and were in a limited number. Therefore, we did not avoid locus-specific effects on genetic structure and diversity, and our results should be evaluated with caution.

\section{Linkage and Hardy-Weinberg equilibria}

We tested for linkage disequilibrium between each pair of microsatellite loci and within each population by using G-exact tests in Genepop 4.0 (Rousset, 2008). Hardy-Weinberg equilibrium (HWE) was tested for each locus and within each population using Genepop 4.0 (Rousset, 2008). We also used the program Microchecker (van Oosterhout et al., 2006) to evaluate whether the presence of genotyping errors may explain hetero- 
TABLE 1. Genetic diversity, Hardy-Weinberg equilibrium and null allele frequency estimations for populations of $C$. barbarus $(C B), C$. italicus $(C I)$ and $C$. wattenwylianus $(C W)$. $A_{r}$ - allelic richness computed for 7 diploid genotypes, He - expected heterozygosity, $H o$ - observed heterozygosity, $D H W E$ - number of loci at Hardy Weinberg disequilibrium (out of 7 for $C B, 6$ for $C I$, and three for $C W$ ), $\hat{r}_{D}$ - Dempster et al. (1977) estimate of null allele frequency. $N$ diploid genotypes were analyzed per population and among them, $\mathrm{N}_{\text {blank }}$ indicates for each population the number of individuals that failed to amplify averaged across loci (i.e. expected to be null homozygotes rather than DNA degraded samples). See Fig. 2 for details of population abbreviations.

\begin{tabular}{|c|c|c|c|c|c|c|c|}
\hline$C B$ & $\mathrm{~N}$ & $N_{\text {blank }}$ & $A_{r}$ & $\mathrm{He}$ & $\mathrm{Ho}$ & DHWE & $\hat{r}_{D}$ \\
\hline F7 & 38 & 2 & 8.19 & 0.884 & 0.614 & 7 & 0.167 \\
\hline Sp1 & 25 & 1 & 9.07 & 0.921 & 0.629 & 6 & 0.183 \\
\hline F13 & 25 & 3 & 8.55 & 0.890 & 0.564 & 6 & 0.228 \\
\hline F10 & 23 & 2 & 8.14 & 0.880 & 0.562 & 6 & 0.200 \\
\hline It & 40 & 7 & 7.91 & 0.810 & 0.471 & 6 & 0.307 \\
\hline F8 & 33 & 2 & 8.01 & 0.873 & 0.570 & 6 & 0.196 \\
\hline F5 & 18 & 2 & 8.65 & 0.904 & 0.643 & 6 & 0.161 \\
\hline F4 & 28 & 3 & 8.52 & 0.902 & 0.578 & 6 & 0.199 \\
\hline F3 & 24 & 2 & 6.94 & 0.852 & 0.575 & 6 & 0.177 \\
\hline $\mathrm{F} 2$ & 12 & 1 & 7.86 & 0.893 & 0.512 & 5 & 0.250 \\
\hline F6 & 25 & 1 & 8.43 & 0.905 & 0.640 & 4 & 0.154 \\
\hline F9 & 28 & 2 & 8.03 & 0.872 & 0.587 & 6 & 0.170 \\
\hline F14 & 14 & 2 & 7.79 & 0.880 & 0.650 & 2 & 0.182 \\
\hline Mean per population sample & 26 & 2 & 8.16 & 0.882 & 0.584 & 5 & 0.198 \\
\hline $\mathrm{CI}$ & $\mathrm{N}$ & $N_{\text {blank }}$ & $A_{r}$ & $\mathrm{He}$ & Ho & DHWE & $\hat{r}_{D}$ \\
\hline F12 & 31 & 2 & 8.96 & 0.920 & 0.642 & 4 & 0.204 \\
\hline F7 & 30 & 2 & 8.84 & 0.909 & 0.691 & 3 & 0.17 \\
\hline F8 & 68 & 3 & 9.18 & 0.920 & 0.705 & 4 & 0.157 \\
\hline $\mathrm{F} 2$ & 34 & 2 & 8.78 & 0.9111 & 0.723 & 3 & 0.165 \\
\hline $\mathrm{Uz}$ & 58 & 9 & 9.09 & 0.914 & 0.655 & 6 & 0.23 \\
\hline Mean per population sample & 44 & 4 & 8.97 & 0.915 & 0.683 & 4 & 0.185 \\
\hline $\mathrm{CW}$ & $\mathrm{N}$ & $N_{\text {blank }}$ & $A_{r}$ & $\mathrm{He}$ & $\mathrm{Ho}$ & DHWE & $\hat{r}_{D}$ \\
\hline $\mathrm{Sp} 2$ & 43 & 2 & 9.71 & 0.934 & 0.662 & 3 & 0.170 \\
\hline Sp3 & 10 & 1 & 9.51 & 0.941 & 0.685 & 2 & 0.190 \\
\hline F13 & 15 & 2 & 8.7 & 0.909 & 0.718 & 1 & 0.200 \\
\hline F10 & 18 & 0 & 8.48 & 0.911 & 0.641 & 3 & 0.152 \\
\hline F11 & 17 & 0 & 8.37 & 0.891 & 0.686 & 1 & 0.087 \\
\hline F7 & 37 & 2 & 8.9 & 0.910 & 0.649 & 3 & 0.161 \\
\hline F8 & 37 & 2 & 8.56 & 0.909 & 0.594 & 3 & 0.205 \\
\hline $\mathrm{F} 1$ & 11 & 1 & 7.67 & 0.872 & 0.652 & 2 & 0.180 \\
\hline Mo & 22 & 2 & 10.38 & 0.952 & 0.606 & 3 & 0.246 \\
\hline Alg & 12 & 1 & 9.54 & 0.923 & 0.612 & 2 & 0.233 \\
\hline Mean per population sample & 22 & 1 & 8.98 & 0.915 & 0.651 & 2 & 0.182 \\
\hline
\end{tabular}

zygote deficiencies. Some DNA samples failed to amplify some loci, suggesting the presence of null alleles. Frequencies of null alleles were estimated using FREENA (Chapuis \& Estoup, 2007) and the Expectation-Maximization algorithm of Dempster et al. (1977). When applicable, multiple tests were controlled for the False Discovery Rate by using R-Library robust-FDR (Pounds et al., 2006). This holds for the following section as well.

\section{Genetic variation within populations}

We estimated the allelic richness corrected for sample size $\left(A_{r}\right)$ using the hierarchical rarefaction approach implemented in HP-RARE (Kalinowski, 2004). Rarefaction was performed using a random sample of 14 gene copies from each population of each species (i.e. 7 diploid genotypes, the minimal number of individuals with a non-blank single-locus genotype over all populations and loci). Expected heterozygosities (He; Nei, 1987) were estimated over all loci using Geneclass2 (Piry et al., 2004). The presence of null alleles result in underestimates of the statistics traditionally used to summarize genetic variation within populations, but this bias is lower for $\mathrm{He}$ and $A_{r}$, particu- larly for large levels of genetic diversity (Chapuis et al., 2008a). We randomly re-sampled populations and loci $(10,000$ iterations with replacement) within each species genotype dataset using a personal program written in Delphi to assess confidence intervals of the expected heterozygosity and allelic richness for a minimum sample size of 14 gene copies.

\section{Genetic variation among populations}

Genotypic differentiation between populations was tested using G-tests with Genepop 4.0.

The levels of global and pair wise population differentiation were quantified by estimating $F_{s t}$ values of Weir (1996), using the ENA method developed by Chapuis \& Estoup (2007) available in FREENA. This method excludes the upper bias that null alleles induce in the $F_{s t}$ calculation. The global estimates are hereafter referred to as $F_{\text {stena), }}$, and their confidence intervals were generated by 10,000 bootstrap re-samplings across loci for each species. In order to compare genetic structuring across species at a similar geographical scale, we also computed a global $F_{\text {stena) }}$ estimate from populations sampled in areas common to all 

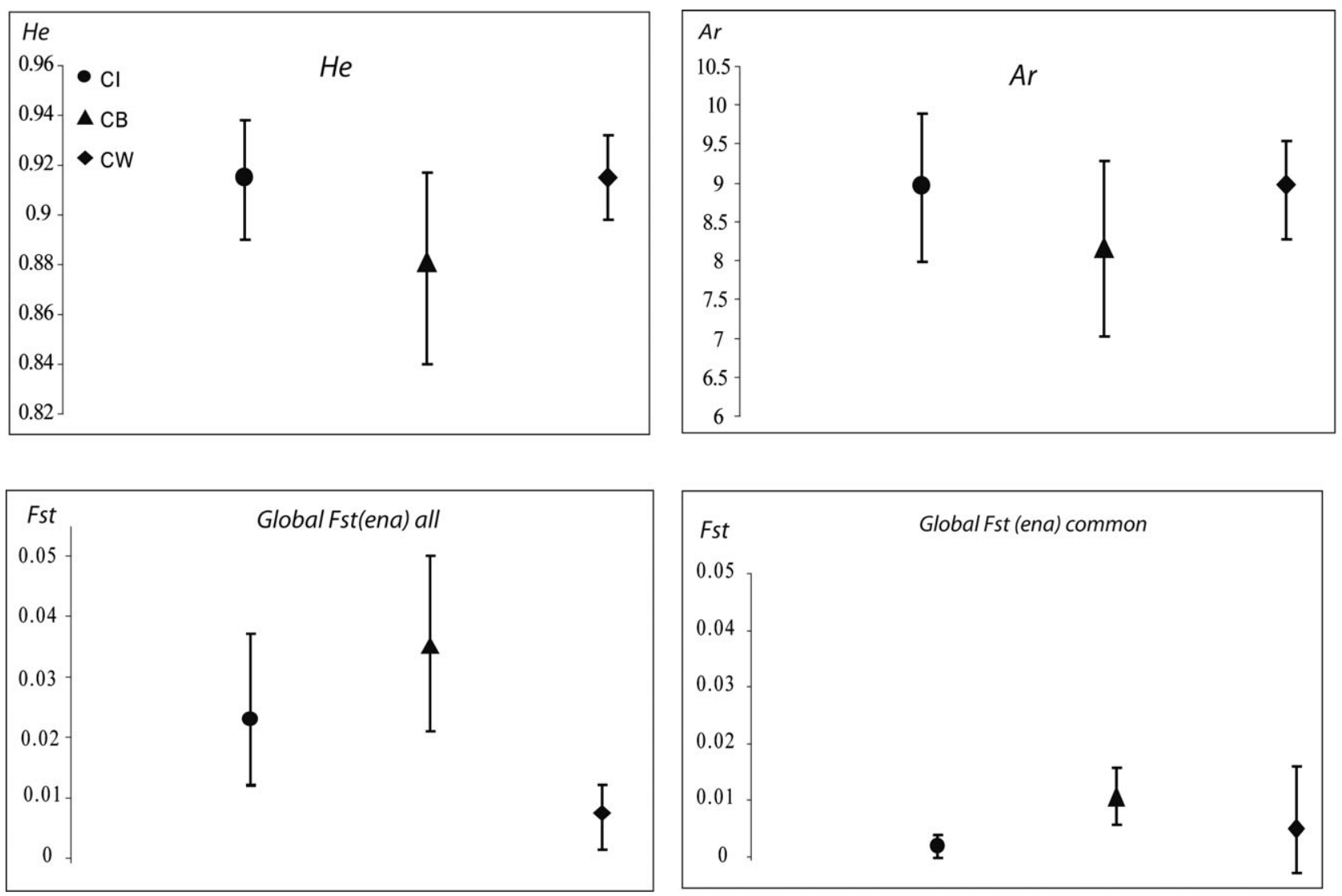

Fig. 3. Mean and 2.5 and 97.5 percent quantile estimates of the expected heterozygosity $(\mathrm{He})$, allelic richness for a minimum

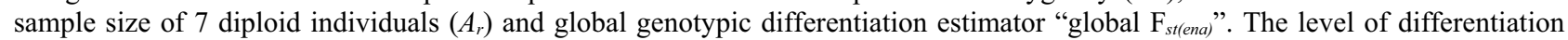
was computed for either all of the populations sampled throughout the range (i.e. all populations; left panel) or a range of similar distances between species (i.e. sampling localities F1/F2, F8, F7 and F12/F13; right panel). C. barbarus (CB), C. italicus (CI), and C. wattenwylianus $(\mathrm{CW})$. Confidence intervals were generated based on 10,000 random re-sampling of sets of loci and populations with replacement. See text for further details.

three species, namely the Pyrénées Orientales, Var and Hérault (populations F1/F2, F12/F13, F7 and F8; see Fig. 1).

A neighbour-joining (NJ) tree (Saitou \& Nei, 1987) defining the relations among all the populations was constructed for each species using chord distance (Cavalli-Sforza \& Edwards, 1967) and software TreeMaker2 (Cornuet et al., CBGP pers. comm.). For producing the correct tree topology the chord distance is the most efficient genetic distance (Takezaki \& Nei, 1996) as it is little affected by null alleles (Chapuis \& Estoup, 2007). Support for each node was assessed by bootstrapping based on 10,000 iterations. Branches were considered well-supported when bootstrap values were higher than $75 \%$. The trees were graphically displayed using FigTree (v1.2.1., Rambaut, 2008).

We then used the Bayesian analysis in the program BAPS 5.2 (Corander et al., 2003, 2008) to estimate the uppermost levels of population structure across the ranges of the species studied. This method clusters the populations sampled into panmictic clusters maximising Hardy-Weinberg and linkage equilibria within them. Because BAPS is better at discriminating gene pools in the presence of null alleles and not accepting more gene pools than there are in reality (Chapuis et al., 2008b), we used the raw microsatellite data set uncorrected for null alleles. For each species, we generated 10 independent runs with the maximum number of clusters set to the number of populations sampled. Because the best partition and its log-likelihood obtained were similar across the 10 runs, we only report that for the first run.
Once the BAPS and NJ treatments determined the clusters of populations that exchanged migrants at a low level, we analyzed the sensible pattern of genetic variation among the populations grouped together within a cluster. In addition, isolation by distance (IBD) was estimated by regressing pairwise estimates of Fst(ena)/[1- Fst(ena)] against distance between sites sampled (Rousset, 1997). Mantel tests were performed to test the correlation between matrices of genetic differentiation and Euclidean geographical distance between the populations sampled using Genepop 4.0 (10,000 permutations) (Rousset, 2008). Because of the poor performance of the exact tests based on only three loci for $C$. wattenwylianus we did not assess the IBD for this species.

\section{RESULTS AND DISCUSSION}

\section{Null alleles}

We did not detect any significant linkage disequilibrium between each pair of microsatellite loci and within each population $(P>0.37)$. For all populations and species, most loci deviated from $H W E$, with a deficiency of heterozygotes $(0.0001<P<0.6991)$. Microchecker (van Oosterhout et al., 2006) indicated the occurrence of null alleles at these loci (i.e. excluded genotyping errors as a source of deviation from $H W E$ ). On average across populations and species, two genotypes out of $\sim 30$ failed to amplify at only a few loci, suggesting the presence null alleles (Table 1). Estimated frequencies of null alleles per 
TABLE 2. Genetic diversity, Hardy-Weinberg equilibrium and null allele frequency estimations for loci of $C$. barbarus $(C B)$, C. italicus $(C I)$ and $C$. wattenwylianus $(C W)$. $A_{r}$ - allelic richness computed for 7 diploid genotypes, $\mathrm{He}$ - expected heterozygosity, $H o$ - observed heterozygosity, $\hat{r}_{D}$ - Dempster et al. (1977) estimate of null allele frequency. See Fig. 2 for details of population abbreviations.

\begin{tabular}{ccccc}
\hline CB & $A_{r}$ & $H e$ & $H o$ & $\hat{r}_{D}$ \\
\hline CB1 & 6.65 & 0.840 & 0.602 & 0.155 \\
CB14 & 8.34 & 0.888 & 0.563 & 0.180 \\
CB17 & 10.14 & 0.929 & 0.539 & 0.277 \\
CB18 & 7.56 & 0.866 & 0.585 & 0.157 \\
CB2 & 8.35 & 0.898 & 0.579 & 0.210 \\
CB8 & 10.02 & 0.942 & 0.740 & 0.137 \\
CB9 & 6.06 & 0.811 & 0.481 & 0.274 \\
Mean per locus & $\mathbf{8 . 1 6}$ & $\mathbf{0 . 8 8 2}$ & $\mathbf{0 . 5 8 4}$ & $\mathbf{0 . 1 9 8}$ \\
\hline CI & $A_{r}$ & $H e$ & $H o$ & $\hat{r}_{D}$ \\
\hline CB14 & 8.47 & 0.904 & 0.555 & 0.254 \\
CB18 & 9.60 & 0.934 & 0.846 & 0.048 \\
CB8 & 7.88 & 0.883 & 0.734 & 0.136 \\
CI11 & 9.47 & 0.930 & 0.765 & 0.174 \\
CI2 & 7.5 & 0.878 & 0.530 & 0.322 \\
CI9 & 10.91 & 0.958 & 0.669 & 0.177 \\
Mean per locus & $\mathbf{8 . 9 7}$ & $\mathbf{0 . 9 1 5}$ & $\mathbf{0 . 6 8 3}$ & $\mathbf{0 . 1 8 5}$ \\
\hline CW & $A_{r}$ & $H e$ & $H o$ & $\hat{r}_{D}$ \\
\hline CB14 & 9.3 & 0.918 & 0.605 & 0.284 \\
CB18 & 9.06 & 0.914 & 0.773 & 0.093 \\
CI9 & 8.58 & 0.913 & 0.574 & 0.198 \\
Mean per locus & $\mathbf{8 . 9 8}$ & $\mathbf{0 . 9 1 5}$ & $\mathbf{0 . 6 5 1}$ & $\mathbf{0 . 1 8 2}$ \\
\hline & & & &
\end{tabular}

locus and per population ranged from 0 to 0.783 in $C$. barbarus, from 0.098 to 0.626 in C. italicus and 0 to 0.479 in C. wattenwylianus (results not shown). The average null allele frequencies over loci and populations were relatively similar between species: 0.198 in $C B$, 0.170 in $C I$ and 0.182 in $C W$ (Table 1). Such a high prevalence of null alleles are frequently reported in population genetic studies of grasshoppers (Zhang et al., 2003; Chapuis et al., 2005, 2008a; Kaatz et al., 2007; Berthier et al., 2008), including those on species of Calliptamus (Blanchet et al., 2010a). We corrected for this by using methods developed recently to account for the effect of null alleles in the analysis of population genetics. Moreover, because mean null allele frequencies were relatively similar in the three species, we expect similar biases in the statistics of their descriptive genetics. Although we attempted to correct for the induced biases in our imperfect data, the results must be interpreted cautiously.

\section{Levels of genetic diversity in three species of Calliptamus}

The mean expected heterozygosities over loci $(\mathrm{He})$ were high in all populations and species. In C. barbarus populations, they varied from 0.810 to 0.921 and averaged 0.882 (Table 1). He averages in C. italicus and $C$. wattenwylianus populations were higher with the same value of 0.915 and ranged from 0.910 to 0.920 and from 0.872 to 0.952 , respectively. Allelic richness $\left(A_{r}\right)$, estimated for a minimum sample size of 14 gene copies, averaged 8.2 alleles per locus in $C$. barbarus populations, with a range of 6.9 to 9.1 , and a similar value of 9.0 alleles per locus was recorded for C. italicus and C. wattenwylianus. $A_{r}$ values ranged from 8.8 to 9.2 alleles per locus in populations of $C$. italicus and 8.4 to 10.4 alleles per locus in those of $C$. wattenwylianus.

The re-sampling distributions of both $\mathrm{He}$ and $A_{r}$ were partly overlapping across the three species (Fig. 3). However, for both of these genetic diversity statistics, the 2.5 percent quartile estimates for the $C$. wattenwylianus and C. italicus distributions were higher than the mean estimates and low ranges of the C. barbarus distributions. The C. barbarus populations from "F3" and "F14" localities, where $C$. wattenwylianus and C. italicus were not sampled, might have partly contributed to the lower levels of genetic diversity in this species (Table 1). However, all seven possible comparisons, using the same localities, showed consistently lower levels of genetic diversity in C. barbarus (see Table 1; C. barbarus versus C. wattenwylianus at F7, F8, F10, F13, and C. barbarus versus C. italicus at F7, F8, and F2). Furthermore, none of the seven $C$. barbarus microsatellite loci seemed to behave as an outlier, and both microsatellite loci common to all three species had lower values of genetic diversity measures in C. barbarus than in either C. italicus or C. wattenwylianus (see CB18 and CB14 in Table 2).

To summarize, the levels of genetic diversity, as measured by expected heterozygosity and allelic richness, tended to be lower in C. barbarus than in the other two species, which were strikingly similar in this respect. Because the sampling of $C$. barbarus was much more extensive than that of the other species, we cannot exclude that environmental factors or histories specific to a few populations, not included in the samples of the other species, might have contributed to the lower level of genetic diversity recorded for this species. Similarly, locus effects on genetic diversity might be expected. However, bootstrap re-sampling of populations and loci showed that the lower halves of the distribution of C. barbarus did not overlap the full distributions of the samples of the other two species. Moreover, the lower genetic diversity in C. barbarus populations remained when only the results for the same localities were compared (see Tables 1 and 2). This finding of a relatively lower genetic diversity in C. barbarus at the species range scale is consistent with what was previously recorded at a fine-scale based on individual samples collected during 2007 using the same sets of loci as in the present study (Blanchet et al., 2012).

The lower estimates of genetic diversity for C. barbarus populations suggest that they had lower harmonic means of effective sizes (Motro \& Thomson, 1982), which primarily reflects effective population sizes during periods of low abundance (e.g. remission periods rather than outbreaks). Interestingly, C. barbarus causes less damage than either of the other Calliptamus species studied, which possibly also indicates that this species with chronically lower initial populations sizes might be less likely to reach the high numbers typical of outbreak events. Finally, the lower levels of genetic diversity 


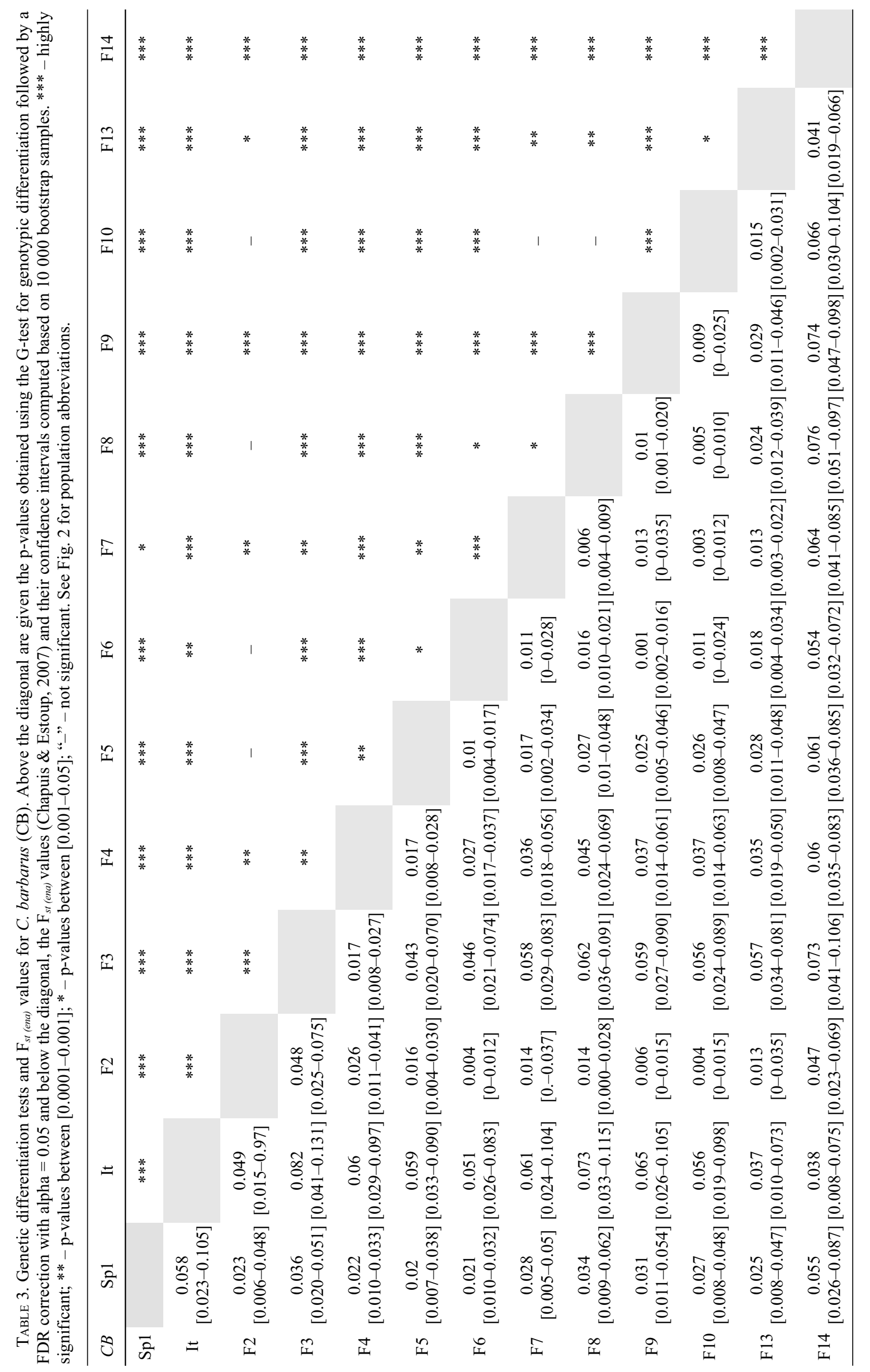


TABLE 4. Genetic differentiation tests and $\mathrm{F}_{\text {stena) }}$ values for $C$. italicus $(\mathrm{CI})$. Above the diagonal are the p-values obtained using the G-test for genotypic differentiation followed by a FDR correction with alpha $=0.05$ and below the diagonal, the $\mathrm{F}_{\text {st(ena) }}$ values (Chapuis \& Estoup, 2007) and their confidence intervals computed based on 10, 000 bootstrap samples. *** - highly significant; ** - p-values between [0.0001-0.001]; * - p-values between [0.001-0.05]. “-” - not significant. See Fig. 2 for population abbreviations.

\begin{tabular}{|c|c|c|c|c|c|}
\hline$C I$ & $\mathrm{~F} 2$ & F7 & F8 & F12 & $\mathrm{Uz}$ \\
\hline $\mathrm{F} 2$ & & - & $*$ & $*$ & $* * *$ \\
\hline F7 & $\begin{array}{c}0.003 \\
{[-0.001-0.008]}\end{array}$ & & $* *$ & - & $* * *$ \\
\hline F8 & $\begin{array}{c}0.007 \\
{[0.001-0.013]}\end{array}$ & $\begin{array}{c}0.005 \\
{[0.001-0.01]}\end{array}$ & & $*$ & $* * *$ \\
\hline $\mathrm{F} 12$ & $\begin{array}{c}0.004 \\
{[0.002-0.007]}\end{array}$ & $\begin{array}{c}0.003 \\
{[-0.001-0.007]}\end{array}$ & $\begin{array}{c}0.002 \\
{[0.000-0.004]}\end{array}$ & & $* * *$ \\
\hline $\mathrm{Uz}$ & $\begin{array}{c}0.042 \\
{[0.024-0.068]}\end{array}$ & $\begin{array}{c}0.046 \\
{[0.019-0.077]}\end{array}$ & $\begin{array}{c}0.042 \\
{[0.021-0.07]}\end{array}$ & $\begin{array}{c}0.039 \\
{[0.019-0.063]}\end{array}$ & \\
\hline
\end{tabular}

recorded within local populations of $C$. barbarus may not only be accounted for by the lower effective sizes of its populations but also by lower gene flow among them (see Fig. 1). As discussed below, we found some evidence for higher genetic structure in C. barbarus.

\section{Levels of genetic differentiation in the three species of Calliptamus}

There was highly significant global genetic differentiation between the populations sampled of each of the species of Calliptamus ( $P$-value $<0.005)$. Genetic differentiation tests were highly significant between most pairs of populations in the C. barbarus and C. italicus data sets (Tables 3 and 4). Unlike in $C B$ and $C I$, we detected significant genotypic differentiation in only three out of the 45 pair wise comparisons of samples from different populations of $C$. wattenwylianus (Table 5). This very low level of significance could reflect little genetic differentiation among populations within this species. However, this lack of a clear differentiation between $C$. wattenwylianus' populations is likely to be partly explained by the low performance of the exact tests when only three loci are used. Indeed, twenty three of the 42 non-significant tests corresponded to $C W$ sample pairs that had $F_{s t}$ values lower than 0.024 but greater than 0.005 , a level of $F_{s t}$ for which exact tests with standard genotyping effort are considered to be powerful (Waples \& Gaggiotti, 2006) (Table 5).

Levels of global genetic differentiation, based on $F_{\text {st (ena) }}$ for all populations, were higher in $C$. barbarus (0.036) than in C. italicus (0.023) and C. wattenwylianus (0.007). Bootstrap re-sampling of populations and loci showed that the distribution of the samples of $C$. wattenwylianus did not overlap the full distributions of the other two species (Fig. 3). The trend for a difference between C. barbarus and $C$. italicus was weaker, but still the upper half of the distribution sample of $C$. barbarus was distinct from the full distribution sample of $C$. italicus. Moreover, for a particular ranges of distances between populations (i.e. from $30 \mathrm{~km}$ to $410 \mathrm{~km}$; see Methods for further details), the distributions of the samples of $C$. barbarus and C. italicus do not overlap (Fig. 3). At this small scale the distribution of $C$. wattenwylianus was wide and overlapped that of the other two species (see Fig. 3).

Tests and levels of genetic differentiation between $C$. wattenwylianus populations indicate that the presumed lower dispersal capacity of this species (Jago, 1963; see Fig. 1) did not translate into noticeably high levels of genetic differentiation. This result, which is based on a wide-scale study, is in contrast to the higher genetic structuring at a fine-scale recorded for this species by Blanchet

TABLE 5. Genetic differentiation tests and $\mathrm{F}_{\text {stena) }}$ values for $C$. wattenwylianus $(\mathrm{CW})$. Above the diagonal are the p-values obtained using the G-test for genotypic differentiation followed by a FDR correction with alpha $=0.05$ and below the diagonal, the $\mathrm{F}_{\text {stena) }}$ values (Chapuis \& Estoup, 2007). For C. wattenwylianus, confidence intervals were not computed because less than four microsatellites were genotyped). $* * *$ - highly significant. ** - p-values between [0.0001-0.001]. * - p-values between [0.001-0.05]. "_" not significant. See Fig. 2 for population abbreviations.

\begin{tabular}{ccccccccccc}
\hline CW & Sp2 & SP3 & F1 & F7 & F8 & F10 & F11 & F13 & Mo & Alg \\
\hline Sp2 & & - & - & - & - & - & - & - & - & - \\
Sp3 & -0.01 & & - & - & - & - & - & - & - & - \\
F1 & 0.016 & 0.024 & & - & - & $* *$ & - & - & - & - \\
F7 & 0.006 & 0.002 & 0.017 & & - & - & - & - & - & - \\
F8 & 0.008 & -0.004 & 0.015 & 0.005 & & - & - & - & - & - \\
F10 & 0.008 & -0.009 & 0.025 & 0.009 & 0.004 & & $* *$ & - & - & $*$ \\
F11 & 0.015 & 0.007 & 0.037 & 0.009 & 0.017 & 0.027 & & - & - & - \\
F13 & 0.003 & -0.001 & 0.013 & -0.001 & 0.010 & 0.014 & 0.015 & & - & - \\
Mo & -0.003 & -0.010 & 0.013 & 0.000 & 0.000 & 0.002 & 0.011 & -0.002 & & - \\
Alg & 0.006 & -0.007 & 0.012 & 0.015 & 0.013 & 0.024 & 0.030 & 0.007 & 0.003 & \\
\hline
\end{tabular}




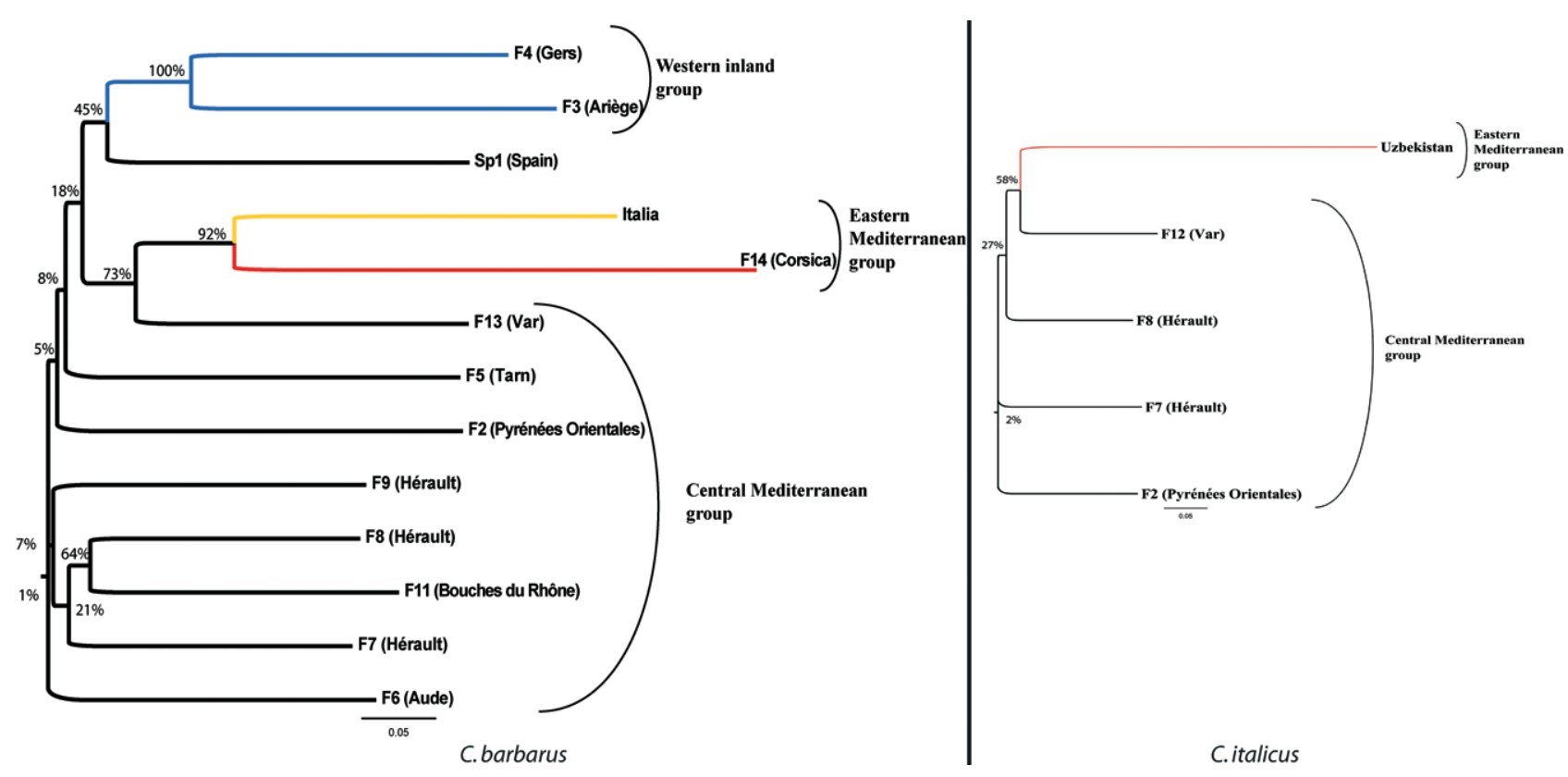

Fig. 4. Neighbour-joining trees of 13 C. barbarus populations (CB) and 5 C. italicus populations (CI), based on Cavalli-Sforza \& Edwards' (1967) distances. Branches were considered well-supported when boostrap values (10,000 replicates) were higher than $75 \%$. Populations with the same branch colour belong to the same genetic cluster as assessed by the Bayesian method of Corander et al. (2008). Groups were defined using BAPS-clustering and NJ-tree analyses and are congruent in the case of the C. italicus population from Uzbekistan. See Fig. 2 for population abbreviations.

et al. (2012). These results should however, be evaluated with caution because very few microsatellite markers for this species were used in this study. Lack of statistical power for this species is indeed evident in the present study. This is not the case for C. barbarus and C. italicus, for which a standard number of markers were used. $C$. barbarus, which reaches outbreak levels less frequently than the other two species, had a higher $F_{s t}$ than $C$. italicus. However, the level of genetic differentiation between populations is maximized by homozygosity (Hedrick, 1999), which was greater in C. barbarus. Hence, we checked that these results remain valid for a standardized measure of $F_{s t}$ (Meirmans, 2006), calculated for genotype datasets that contain null alleles, following the method of Brouat et al. (2007). The genetic differentiation measure remained higher in $C$. barbarus than in $C$. italicus at both a large scale $\left(F_{\text {st(ena) }}^{\prime}=0.36\right.$ versus 0.32$)$ and common scale $\left(F_{\text {st(ena) }}^{\prime}=0.14\right.$ versus 0.06$)$. Moreover, we detected significant isolation by distance among the nine $C$. barbarus populations belonging to the main genetic cluster $\left(P\right.$-value $=0.041, \mathrm{R}^{2}=0.156$ and see the central Mediterranean group in Fig. 4). By contrast, no evidence of IBD was detected among the five populations of $C$. italicus $\left(P\right.$-value $\left.=0.1026 ; \mathrm{R}^{2}=0.988\right)$.

Our results are in agreement with those of the intraspecific comparative survey of the outbreak locust, $L$. migratoria, which shows that genetic differentiation was substantially greater among non-outbreak populations than among outbreak populations (Chapuis et al., 2009). In this locust, high population densities during outbreaks induce a phase change, which results in the indivuals aggregating and forming swarms. These important phenotypically plastic changes in traits of migratory behaviour of the gregarious phase in locusts may result in an increase in the rate and/or distance of effective migration by gregarious populations. This behavioural hypothesis is less likely to explain the greater gene flow recorded among populations of Calliptamus spp., in outbreak areas, which do not express phase polyphenism. Alternatively, populations of those species of Calliptamus that reach outbreak levels may produce a larger number of effective migrants than non-outbreak populations simply because they frequently experience high population densities (Chapuis et al., 2009).

\section{Barriers to gene flow across the species' ranges}

The BAPS analysis and Neighbour joining tree detected large-scale patterns in genetic population structure across the ranges sampled (Fig. 4). BAPS revealed four population clusters in C. barbarus, two in C. italicus and one in C. wattenwylianus (Likelihood of the model $=-13715.6$, -7790.1 , and -4723.9 respectively). In C. italicus, only the easterly distant population (i.e. from Uzbekistan) was separated from the core populations (i.e. central Mediterranean group). The main cluster of $C$. barbarus includes a set of populations widely distributed along the northern Mediterranean coast (see central Mediterranean group in Fig. 4), which includes southern French populations from Hérault, Var, Pyrénées Orientales, Tarn, Aude and Bouches du Rhône (F10) departments and populations from Northern Spain ( $\mathrm{Sp}$ ). The relationships among these populations could not be resolved further (low bootstrap values in the NJ-tree, Fig. 4), suggesting high levels of gene flow. Furthermore, two $C B$ populations located inland and in the western part of the regions sampled in France were sorted into a separate single genetic group 
(see western inland group in Fig. 4). Another genetic group included populations that were both geographically distant from the core populations and isolated either by the Mediterranean Sea (Corsica Island) or Alps (Italy) (Fig. 4). These two populations were further identified as distinct genetic clusters by the BAPS analysis.

Strong bio-geographic effects of barriers, such as the Mediterranean Sea, in the case of the $C B$ population on the Island of Corsica or Alps in the case of the Italian population, on gene flow were not surprising. However, it is interesting to note that the Spanish population was placed in the same genetic cluster as the French samples collected on the other side of the Pyrenean chain (see central Mediterranean group). Because $C$. barbarus is recorded at an altitude of $1300 \mathrm{~m}$ in the Pyrenees (Olmo Vidal, 2006) and at $2300 \mathrm{~m}$ in Afghanistan (Jago, 1963), mountains may represent only weak ecological barriers to gene flow in this species and the Italian genetic cluster may also be explained by its distance from the area where most populations were sampled. C. italicus is also recorded at high altitudes (in Italy; Fontana et al., 2002), but as only four French samples of this species were collected we were unable to effectively test its genetic structure along mountain barriers. Olmo Vidal (2006) did not find $C$. wattenwylianus at altitudes greater than $600 \mathrm{~m}$. Thus, in this species, mountains might be a stronger barrier to gene flow, but this hypothesis remains to be tested. A proper identification of the bio-geographical barriers would require a more intensive sampling of populations in the Central and Eastern ranges of the three species.

ACKNOWLEDGEMENTS. We are grateful to CIRAD and Région Languedoc Roussillon for their financial support. M.-P. Chapuis was supported by a Marie-Curie Outgoing Fellowship within the Sixth European Community Framework Programme during the first part of this study. We thank K. Berthier, P.-A Gagnaire and P. Berrebi for their comments. We are grateful to the following people who helped with the sampling: M. CocaAbia, E. Muniez, D. Petit, Y. Braud, M. Lazar, F.-M. Buzetti and R. Peveling.

\section{REFERENCES}

AlLÉGUÈDE R. 1946: Les pullulations de Criquet italien (Calliptamus italicus L.) dans les Charentes. Bull. Sem. Office Nat. Anti-Acr. 4: 23-34.

AlLÉGUÈDE R. 1948: Les pullulations de Criquets italiens dans le sud-ouest. Rev. Zool. Agric. Appl. (Bordeaux) (No. Spéc.): 44-50.

Bailey N.W., Gwynne D.T. \& Ritchie M.G. 2007: Dispersal differences predict population genetic structure in Mormon crickets. Mol. Ecol. 16: 2079-2089.

Belayneh Y.T. 2005: Acridid pest management in the developing world: a challenge to the rural population, a dilemma to the international community. J. Orthopt. Res. 14: 187-195.

Berthier K., Loiseau A., Streiff R. \& Arlettaz R. 2008: Eleven polymorphic microsatellite markers for Oedaleus decorus (Orthoptera, Acrididae), an endangered grasshopper in Central Europe. Mol. Ecol. Resour. 8: 1363-1366.

Blanchet E., Pages C., Blondin L., Billot C., Rivallan R., Vassal J., Lecoq M. \& Risterucci A. 2010a: Isolation of microsatellite markers in the Calliptamus genus (Orthoptera, Acrididae). J. Insect Sci. 10: 133.
Blanchet E., Blondin L., Gagnaire P.-A., Foucart A., Vassal J.-M. \& LECOQ M. 2010b: Multiplex PCR assay to discriminate four neighbour species of the Calliptamus genus (Orthoptera: Acrididae) from France. Bull. Entomol. Res. 100: 701-706.

Blanchet E., Lecoq M., Pages C., Rivallan R., Foucart A., Billot C., Vassal J.M., Risterucci A.M. \& Chapuis M.P. 2012: A comparative analysis of fine-scale genetic structure in three closely-related syntopic grasshopper species (Calliptamus sp.). Can. J. Zool. 90: 31-41.

Brouat C., Loiseau A., Kane M., Ba K. \& Duplantier J.M. 2007: Population genetic structure of two ecologically distinct multimammate rats: the commensal Mastomys natalensis and the wild Mastomys erythroleucus in southeastern Senegal. Mol. Ecol. 16: 2985-2997.

Buzzetti F.M., Fontana P., Mori N. \& Girolami V. 2005: Locust infestations in Lessinia Infestazione di cavallette in Lessinia. Informat. Agr. 61: 75-76.

Cavalli-Sforza L.L. \& Edwards A.W. 1967: Phylogenetic analysis. Models and estimation procedures. Am. J. Human Genet. 19: 233-257.

Chapuis M.P. \& Estoup A. 2007: Microsatellite null alleles and estimation of population differentiation. Mol. Biol. Evol. 24: 621-631.

Chapuis M.P., Loiseau A., Michalakis Y., Lecoq M. \& Estoup A. 2005: Characterization and PCR multiplexing of polymorphic microsatellite loci for the locust Locusta migratoria. Mol. Ecol. Notes 5: 554-557.

Chapuis M.P., Lecoq M., Michalakis Y., Loiseau A., Sword G.A., PIRY S. \& Estoup A. 2008a: Do outbreaks affect genetic population structure? A worldwide survey in Locusta migratoria, a pest plagued by microsatellite null alleles. Mol. Ecol. 17: $3640-3653$.

Chapuis M.P., Estoup A., Auge-Sabatier A., Foucart A., Lecoq M. \& MichalaKis Y. 2008b: Genetic variation for parental effects on the propensity to gregarise in Locusta migratoria. BMC Evol. Biol. 8: 37.

Chapuis M.P., Loiseau A., Michalakis Y., Lecol M., Franc A. \& Estoup A. 2009: Outbreaks, gene flow and effective population size in the migratory locust, Locusta migratoria: a regional-scale comparative survey. Mol. Ecol. 18: 792-800.

Chapuis M.-P., Popple J.-A., Berthier K., Simpson S.J., Deveson T., Spurgin P., Steinbauer M.J. \& Sword G.A. 2011: Challenges to assessing connectivity between massive populations of the Australian Plague locust. Proc. R. Soc. Lond. (B) 278: 3152-3160.

Chara B. 1987: Etude comparée de la biologie et de l'écologie de Calliptamus barbarus (Costa, 1836), et de Calliptamus wattenwylianus (Pantel, 1896) (Orthoptera, Acrididae) dans l'ouest algérien. $\mathrm{PhD}$ Thesis, Université d'Aix-Marseille, 190 pp.

Chopard L. 1951: Orthoptéroïdes. Paul Lechevalier, Paris, 359 pp.

COPR 1982: The Locust and Grasshopper Agricultural Manual. Centre for Overseas Pest Research, London, $690 \mathrm{pp}$.

Corander J., Waldmann P. \& Sillanpaa M.J. 2003: Bayesian analysis of genetic differentiation between populations. Genetics 163: 367-374.

Corander J., Marttinen P., Siren J. \& Tang J. 2008: Enhanced Bayesian modelling in BAPS software for learning genetic structures of populations. BMC Bioinformatics 9: 539.

Del CAÑIzo J. 1940: Las plagas de langosta en Espana. In: Proceedings of the 6th International Congress of Entomology, Madrid, 6-12 Sep. 1935. Vol. 2. Museo de Ciencias Naturales, S. Aguirre, pp. 845-865. 
Dempster A.P., Laird N.M. \& Rubin D.B. 1977: Maximum Likelihood from Incomplete data via the EM algorithm. J. R. Statist. Soc. (B) 39: 1-38.

Doumandi S., Doumandi-Mitiche B., Khoudour A. \& Benzara A. 1993: Grasshoppers and Crickets Pullulation in Bordj Bou Arreridj Region (Algeria). Meded. Fac. Landbouwk. Toegep. Biol. Wetensch. Univer. Gent 58: 329-337.

FAO 1994: The Desert Locust Guidelines. Food and Agriculture Organization of the United Nations, Rome, $43 \mathrm{pp}$.

Fontana P., Buzzeti F.M., Cogo A. \& OdÉ B. 2002: Guida al riconoscimento e allo studio di cavallette, grilli, mantidi e insetti affini del Veneto. Museo Naturalistico Archeologico, Vicence, $592 \mathrm{pp}$.

Harz K. 1975: Die Orthopteren Europas. The Orthoptera of Europe. Dr W. Junk, Haag, 939 pp.

Hedrick P.W. 1999: Perspective: Highly variable loci and their interpretation in evolution and conservation. Evolution 53: 313-318.

HedRICK P.W. 2005: A standardized genetic differentiation measure. Evolution 59: 1633-1638.

JAGO N.D. 1963: A revision of the genus Calliptamus Serville (Orthoptera: Acrididae). Bull. Br. Mus. Nat. Hist. (Entomol.). 13: $290-350$.

KaAtz H.H., Ferenz H.J., Langer B. \& Moritz R.F.A. 2007: Isolation and characterization of nine polymorphic microsatellite loci from the desert locust, Schistocerca gregaria. Mol. Ecol. Notes 7: 1042-1044.

KaLINOWSKI S.T. 2004: Counting alleles with rarefaction: Private alleles and hierarchical sampling designs. Conserv. Genet. 5: $539-543$.

Latchininsky A. \& Gapparov F.A. 1996: Les conséquences du dessèchement de la mer d'Aral sur la situation acridienne dans la région. Sécheresse 7: 109-113.

Latchininsky A., Sword G.A., Sergeev M.G., Cigliano M. \& LECOQ M. 2011: Locusts and grasshoppers: Behavior, ecology and biogeography. Psyche, Article ID 578327, 4 pp., doi: $10.1155 / 2011 / 578327$

LeCOQ M. 2003: Desert locust threat to agricultural development and food security and FAO international role in its control. Arab. J. Plant Prot. (Beyrouth) 21: 188-193.

Louveaux A., Peyrelongue J.Y. \& Gillon Y. 1988: Analyse des facteurs de pullulation du Criquet italien Calliptamus italicus (L.) en Poitou-Charentes. C. R. Séanc. Acad. Agr. 74: 91-102.

Magor J.I., Lecoq M. \& Hunter D.M. 2008: Preventive control and Desert Locust plagues. Crop Prot. 27: 1527-1533.

McCoy K.D., Boulinier T. \& Tirard C. 2005: Comparative host-parasite population structures: disentangling prospecting and dispersal in the black-legged kittiwake Rissa tridactyla. Mol. Ecol. 14: 2825-2838.

Meirmans P.G. 2006: Using the AMOVA framework to estimate a standardized genetic differentiation measure. Evolution 60: 2399-2402.

Motro U. \& Thomson G. 1982: On heterozygosity and the effective size of populations subject to size changes. Evolution 36: 1059-1066.

NeI M. 1987: Molecular Evolutionary Genetics. Columbia University Press, New York, $512 \mathrm{pp}$.

Olmo Vidal J.M. 2006: Altes Ortòpters de Catalunya i llibre vermell. Generalitat de Catalunya, Barcelona, $428 \mathrm{pp}$.

Ortego J., Aguirre A. \& Cordero P.J. 2011: Fine-scale spatial genetic structure and within population male-biased gene flow in the grasshopper Mioscirtus wagneri. Evol. Ecol. 25: $1127-1144$

Pener M.P. \& Simpson S.J. 2009: Locust phase polyphenism: an update. Adv. Insect Physiol. 36: 1-286.
Piry S., Alapetite A., Cornuet J.M., Paetkau D., Baudouin L. \& Estoup A. 2004: GENECLASS2: A software for genetic assignment and first-generation migrant detection. J. Hered. 95: $536-539$.

Pounds S. \& CHENG C. 2006: Robust estimation of the false discovery rate. Bioinformatics 22: 1979-1987.

Reinhardt K., Kohler G., MaAs S. \& Detzel P. 2005: Low dispersal ability and habitat specificity promote extinctions in rare but not in widespread species: the Orthoptera of Germany. Ecography 28: 593-602.

Rousset F. 1997: Genetic differentiation and estimation of gene flow from F-statistics under isolation by distance. Genetics 145: $1219-1228$.

RousSET F. 2008: GENEPOP' 007: a complete re-implementation of the GENEPOP software for Windows and Linux. Mol. Ecol .Resour. 8: 103-106.

SAITOU N. \& NeI M. 1987: The neighbor-joining method: a new method for reconstruction of phylogenetic trees. Mol. Biol. Evol. 4: 406-425.

SimPSON S.J. \& SwORD G.A. 2009: Phase polyphenism in locusts: mechanisms, population consequences, adaptive significance and evolution. In Whitman D. \& Ananthakrishnan T.N. (eds): Phenotypic Plasticity of Insects: Mechanisms and Consequences. Science Publishers, Einfield, pp. 145-189.

Simpson S.J., Sword G.A. \& Lo N. 2011: Polyphenism in insects. Curr. Biol. 21: 738-749.

Steedman A. 1988: Locust Handbook. Overseas Development Natural Resources Institute, London, $180 \mathrm{pp}$.

Sword G.A., Lecoq M. \& Simpson S.J. 2010: Phase polyphenism and preventative locust management. J. Insect Physiol. 56: 949-957.

TAKEZAKI N. \& NeI M. 1996: Genetic distances and reconstruction of phylogenetic trees from microsatellite DNA. Genetics 144: 389-399.

Uvarov B.P. 1966: Grasshoppers and Locusts. A Handbook of General Acridology. I: Anatomy, Physiology, Development, Phase-Polymorphism, Introduction to Taxonomy. University Press, Cambridge, UK, 475 pp.

Uvarov B. 1977: Grasshoppers and Locusts, Vol. 2. Centre for Overseas Pest Research, London, 613 pp.

van Oosterhout C., Weetman D. \& Hutchinson W.F. 2006: Estimation and adjustment of microsatellite null alleles in nonequilibrium populations. Mol. Ecol. Notes 6: 255-256.

WAPLES R.S. \& GAGGIOTI O. 2006: What is a population? An empirical evaluation of some genetic methodes for identifying the number of gene pools and their degree of connectivity. Mol. Ecol.15: 1419-1439.

WeIR B.S. 1996: Genetic Data Analysis II. Methods for Discrete Population Genetic Data. Sinauer, Sunderland, MA, 445 pp.

Zhang D.X., Yan L.N., Ji Y.-J., Hewitt G.M. \& Huang Z.S. 2009: Unexpected relationships of substructured populations in Chinese Locusta migratoria. BMC Evol. Biol. 9: 144.

Zhang D.-X., Yan L.-N., Ji Y.-J., Kang L., Hewitt G.M. \& HuANG Z.-S. 2003: Isolation, characterization and crossspecies amplification of eight microsatellite DNA loci in the migratory locust (Locusta migratoria). Mol. Ecol. Notes 3: 483-486.

Zheng X.Y., Zhong Y., Duan Y.H., Li C.X., Dang L., Guo Y.P. \& MA E.B. 2006: Genetic variation and population structure of oriental migratory locust, Locusta migratoria manilensis, in China by allozyme, SSRP-PCR, and AFLP markers. Biochem. Genet. 44: 333-347.

Received December 6, 2011; revised and accepted March 9, 2012 